\title{
Architecture_MPS
}

Interview article

\section{A Critical Architecture - Comments on Politics and Society}

Kenneth Frampton 1, Graham Cairns 2,

How to cite: Frampton, K., Cairns, G. 'A Critical Architecture - Comments on Politics and Society.' Architecture_MPS, 2012, 1(1): 4, pp. 1-15. DOI:

https://doi.org/10.14324/111.444.amps.2012v1i4.001.

Published: 01 December 2012

\section{Peer Review:}

This article has been through the journal's standard Editorial review.

\section{Copyright:}

(c) 2012, The Author(s). This is an Open Access article distributed under the terms of the Creative Commons Attribution License (CC-BY) $2.0 \mathrm{https}: / /$ creativecommons.org/licenses/by/2.0/, which permits re-use, distribution and reproduction in any medium, provided the original author and source are credited • DOI: https://doi.org/10.14324/111.444.amps.2012v1i4.001

\section{Open Access:}

Architecture_MPS is a peer-reviewed open access journal. 


\title{
Title: A Critical Architecture - Comments on Politics and Society
}

\author{
Kenneth Frampton
}

Architecture_media_politics_society. vol. 1, no.4.

December 2012

Affiliation: Faculty of Architecture, Columbia University, New York.

\begin{abstract}
:
Over a fifty year career as an architectural critic and historian Kenneth Frampton has consistently defended the Modernist agenda of the Twentieth Century. However, he has also been fiercely critical of its failings and shortcomings. He has taught at the world's most prestigious institutions, produced a body of work that can be defined as kaleidoscopic and has written texts which have become part of the canon of architectural history and theory. His encyclopedic Modern Architecture: a Critical History, is in its fourth edition and still remains a bedrock text for our understanding of the Modern Movement more than twenty years after its initial publication. His ground-breaking essay of 1983, Towards a Critical Regionalism: Six Points for an Architecture of Resistance set the agenda for a reconsideration of Modernism that continues to resonate today. He has published internationally on a whole range of issues and remains committed to a critical analysis of Modernism which places architecture firmly in the context of the social and political milieu of the left.

In this fifty year career, the ideas of the social and political theorist Hannah Arendt have operated as a form of conceptual and ethical foundation. His 1979 essay, The Status of Man and the Status of his Objects, is a form of analysis of her theories that explores, amongst other things, her distinction between work and labour in the specific context of architecture. This essay is also given primary importance in his 2002 book Labour, Work and Architecture: Collected Essays on Architecture and Design, which he dedicates to the memory of Arendt. In his 1979 essay, he suggests that reading Arendt's work in 1965 illuminated the "invariably confusing distinction between building (as process) and architecture (as stasis)", with architecture having as its primary charge the creation of the public realm. He begins this interview-article by summarising these themes, but also by drawing out the relevance of Arendt's ideas in the context of contemporary commodified culture. He goes on to explore a whole range of other ideas including the mediatisation of architecture, high rise development, suburbia and the role of government in the architecture of the United States and the United Kingdom.
\end{abstract}




\section{Title: A Critical Architecture: Comments on Politics and Society}

\section{Kenneth Frampton}

Interviewer / author - Graham Cairns

Research - Rachel Isaac-Menard

Architecture_media_politics_society. vol.1, no.4.

December 2012

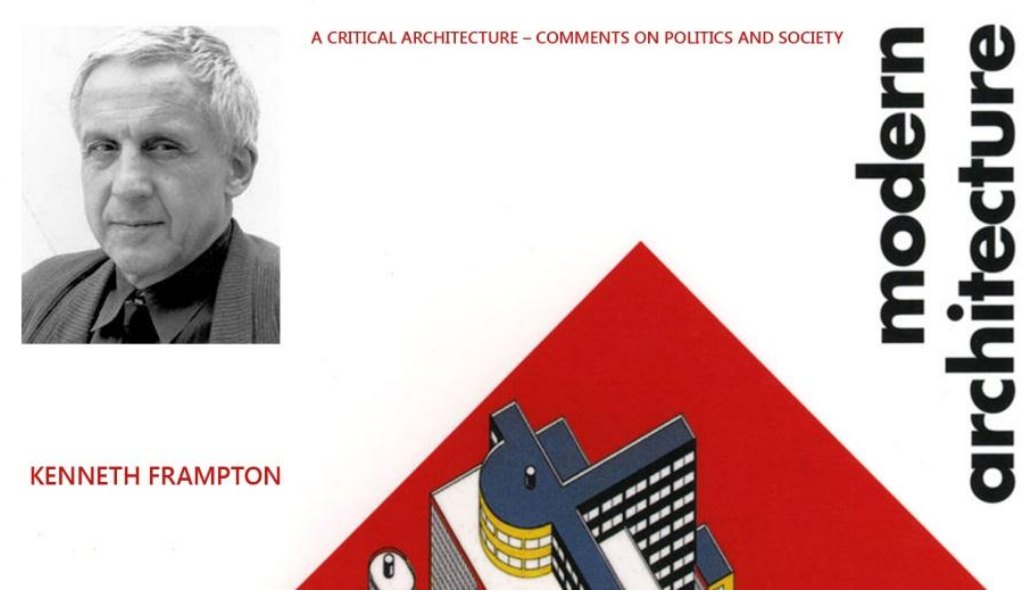

Over a fifty year career as an architectural critic and historian Kenneth Frampton has consistently defended the modernist agenda of the Twentieth Century. However, he has also been fiercely critical of its failings and shortcomings. He has taught at the world's most prestigious institutions, produced a body of work that can be defined as kaleidoscopic and has written texts which have become part of the canon of architectural history and theory. His encyclopedic Modern Architecture: a Critical History, is in its fourth edition and still remains a bedrock text for our understanding of the Modern Movement more than twenty years after its initial publication. His ground-breaking essay of 1983, Towards a Critical Regionalism: Six Points for an Architecture of Resistance set the agenda for a reconsideration of Modernism that continues to resonate today. He has published internationally on a whole range of issues and remains committed to a critical analysis of Modernism which places architecture firmly in the context of the social and political milieu of the left.

In this fifty year career, the ideas of the social and political theorist Hannah Arendt have operated as a form of conceptual and ethical foundation. His 1979 essay, The Status of 


\section{Amps}

Man and the Status of his Objects, is a form of analysis of her theories that explores, amongst other things, her distinction between work and labour in the specific context of architecture. ${ }^{1}$ This essay is also given primary importance in his 2002 book Labour, Work and Architecture: Collected Essays on Architecture and Design, which he dedicates to the memory of Arendt. ${ }^{2}$ In his 1979 essay, he suggests that reading Arendt's work in 1965 illuminated the "invariably confusing distinction between building (as process) and architecture (as stasis)," with architecture having as its primary charge the creation of the public realm. ${ }^{3} \mathrm{He}$ begins this interview-article by summarising these themes, but also by drawing out the relevance of Arendt's ideas in the context of contemporary commodified culture.

The thing that impressed me in the thinking of Hannah Ardent was this distinction between "work" and "labour". ${ }^{4}$ The notion that in the process of labour man mixes with his 'product.' Labour thus becomes analogous to life itself; it becomes a question of the biological life cycle in a sense. There are of course overtones of Marx in this as well. However, she plays this idea off against the notion of "work"; as that mode of production resulting in objects that are not meant to be consumed. Work is thus seen as involving notions of memory and identity. This duality is very interesting and captures the dual character of architecture; as something lived in the here and now on the one hand, and as something operating as symbolic and transcending the present on the other. ${ }^{5}$

She also defines labour as "the state of affairs in which that which is produced is meant to be consumed." Later, she says that "we must consume our houses, our cars our furniture etc., less like the good fruits of the earth"; goods that would perish if not consumed. It is a statement that brings us to the idea of commodification - although she does not necessarily use this term vis-à-vis the current scene in culture or architecture specifically.

In developing a theory of commodification from Arendt, I would link it with Guy Debord's idea of 'the society of the spectacle'; an idea developed slightly later but which remains relevant today. ${ }^{6}$ Its relevance is obvious when we consider the phenomenon of the star architect and star architecture, but it is also relevant in the context of the phenomenon of the intense, high speed global development across the globe we see today.

The projects we are seeing under construction, and already constructed, in places like China, as well as India and the Middle East, can all be defined as products of commodification and spectacle; the Burj Tower in Dubai and the CCTV building in Bejing are just two examples. ${ }^{7}$ These extremely large buildings that are primarily capitalist development; that are very exploitative; that are pure speculation... they are huge objects that are more or less culturally meaningless. Considered in the context of the spectacle and the commodity, this huge global capitalist architecture has become an enormous commodifying operation in itself.

Considering the question of the scale of commercial architecture in these places reminds one of Tadao Ando in a certain regard. Not in terms of his architecture, but in the context of a comment he came very close to making about high rise commercial construction. In the years following the construction of the 


\title{
Amps
}

Hong Kong and Shanghai bank building by Norman Foster, he was approached by a developer who asked him to design "something comparable. ${ }^{8}$ Ando says that "I accepted the project for two weeks and then I gave it back."

The explanation he gives of his rationale amounted to saying that "over a certain height architecture is no longer possible." Of course Ando doesn't specify the height he is referring to, but he has never built any sort of definitive high rise. His architecture remains rooted to the ground. Now, despite the statement being aphoristic it is very powerful - and of potentially fundamental importance in the context of contemporary development. In some ways it links us back to the ideas of Arendt in terms of public space and, indeed, architecture as stasis.

\begin{abstract}
This paraphrasing of Tadao Ando reveals a reticent interest the history of the high rise as a peculiar architectural problem. It is an issue of particular resonance in the context in which Kenneth Frampton lives and works, New York City, and is a theme he mentions in his broad sweep of architectural history; Modern Architecture: A Critical History. ${ }^{9}$ It is a specific architectural issue intrinsically intertwined with the emergence of the modern American and European city, which has also been a theme to emerge in his writings over the decades. ${ }^{10}$ In this context, he expands on the Ando's arguments from an historical perspective:
\end{abstract}

Although the tall building, in Ando's terms, excludes the possibility of "architecture," the high rise does function as an icon and, indeed at times, as a cultural symbol. In the context of this city, where developers control everything, they function as symbols of a culture of money. This was true historically because, despite the 1811 plan that produced the brilliant Central Park, New York was a city with no future plan for development. This remains the case today. As a result, the high rise still inevitably operates as a social and, by extension, ideological symbol in and for the city; and the United States more generally. ${ }^{11}$

If we consider the origin of the high rise in these terms it is very interesting. It emerges in the aftermath of the Civil War, at a time when the wealth and power of the United States had a mission; to create a 'bourgeois civilisation' that would be as good as, and even surpass, the European model; the Enlightenment and École des Beaux Arts model. Leonardo Benevelo suggests that the reason why the École des Beaux Arts was the mode of teaching during that period was that to produce buildings that would represent the triumph of this economic and civilizing expansion in North America, one needed to be able to 'educate people' in a code; a code that could be taught and read in relation to the European model. $^{12}$

It is in this sense that the nineteenth century skyscraper becomes interesting. In this context the American architects of the time begin to confront this new issue of height alongside the question of style. When you look at the nineteenth century skyscraper you see the problem of bottom, middle and top being addressed, and the various aesthetic and compositional responses that emerged to that particular formal problem. In Cass Gilbert's Woolworth building we see one of the more pathological responses to it. Cass Gilbert saw in the Gothic the potential, in a vulgar way, to address the problem of the tall building artistically considered. 


\title{
Amps
}

His response was developed in a much more sophisticated way by Sullivan, using a more classical style. ${ }^{13}$ In a sense, it was a repetition of the bankrupt 'battle of the styles' in which American architects looked to the 'other' for answers and, as a result, their ornament was from this 'other.' Sullivan's response however, was much more organic and brings us to a very interesting question; the debate about whether culture or nature was to be the origin of the new culture. It is in this context that, in Owen Jones' "Grammar of Ornament," 14 we get the suggestion that we can create ornament out of nature; something directly taken up in Art Nouveau.

So the question of height, a global issue today that for architects like Ando is still unresolved, is deep rooted in the United States. Indeed, the American skyscraper was an endless struggle to somehow solve this problem; a problem which, in its origins, was intrinsically linked to the creation of the new identity and culture emerging in the late nineteenth century and early twentieth century in this country. If one was to take Ando's description literally, this new cultural identity did not have 'architecture,' it had 'buildings' which then had to be decorated with ornament to function symbolically.

\begin{abstract}
In these comments Frampton reveals one of the characteristics of his understanding of architecture as a socio-cultural phenomenon; architecture as a sort of amalgam of multiple and occasionally conflicting influences. In Modern Architecture: A Critical History, his explanation of the emergence of modern architecture encompasses a plethora of technological, political, economic and cultural issues. ${ }^{15}$ In this context, technological developments of the Otis elevator and the development of steel as a construction material then, are seen as operative alongside other factors in the emergence of the high rise; population growth in late nineteenth century industrial cities and rising real estate values in the emerging Western metropolis for example. In his comments here, he overlays such factors with a reading of cultural symbolism; the emergence of the United States as a new social and political force that sought to establish its own architectural identity. They are thoughts that lead to comments on architecture as a twentieth century political symbol operative through the media.
\end{abstract}

By the twentieth century the symbolic use of architecture in cultural and political contexts shifted definitively. Political symbolism would not only be evident in the realm of architecture, it had moved into the realm of the media. I think the point and the place in which architecture ceased to be the main mode of representations of power - economic or political - was not in the early twentieth century American commercial high rise building however, but a few decades later in Nazi Germany; specifically in the Nuremberg Rally of 1934.

This a very interesting moment. Albert Speer's so-called Cathedral of Light involves creating space solely by search lights. It becomes immaterial. However, not only through his search lights, but also later when it appears in Leni Riefenstahl's film The Triumph of the Will. In reality Albert Speer's Nuremberg Rally site was architecture; it was made out of very solid material. ${ }^{16}$ Nevertheless, the most powerful image to emerge from it was that of the search lights.

A similar thing occurs when it becomes a kind of set for parts of The Triumph of the Will. It is architecture produced through Speer, and the ideology of the Third Reich, but the whole thing has its main representation of ideological power on film. The thing has its greatest power not as architecture, but 


\title{
Amps
}

as media. It is a historical moment in which the representation of power shifts away from architecture. ${ }^{17}$

In a book called the Twelve Year Reich by Richard Grunberger, there's the most amazing photograph of a radio reporter. ${ }^{18} \mathrm{He}$ is holding a microphone down two feet off the ground as German troops are marching past. He is getting the oral effect; the oral representation of power. It is another example of the way in which this period saw an explosion in the use of the media for representations of power; none of which were architectural.

I think the Third Reich is this moment when the primary representation of power shifts to the media. In a sense, it opens up for us a relatively direct lineage to the commodification of architecture we mentioned earlier - and the star architect syndrome; both phenomenon that operate through the media. Today, we live in a world saturated by the media.

\begin{abstract}
In discussing this drift away from architecture towards the media, Frampton suggests that when we analyse contemporary architecture there is, in addition to technological, economic and the cultural factors, yet one more layer to consider today; the idea of the image, the spectacle and the intrinsically linked commodity culture. This type of complex and multi layered understanding of architecture has informed his writings on the architecture in various essays throughout his career. The topic of many of these is not restricted to the architecture of the spectacle, whether the political symbol or the commercial high rise, they deal with what we may call the "everyday." Here, he goes on to discuss the "everyday" architecture of suburbia in exactly these terms; as a complex product of the age of the automobile, the telecommunications industries and the commercialisation of American and European ways of living in the second half of the twentieth century:
\end{abstract}

If there is a modern invention that is apocalyptical, it is not the atomic bomb. It is the automobile. That may seem to be a slightly eccentric opinion, but I deeply believe it. The current crisis of the climate is very much linked to the automobile in multiple ways - and not just through their direct and incredibly rapid consumption of natural resources such as gasoline. Another less direct example, with global implications, is the destruction of the rainforest. The rainforest would not have been touched if it had not been for the automobile. Fixed rail technology would not have been able to penetrate into the rainforest as the automobile has done. It goes everywhere. It is the consuming machine par excellence.

When one considers the latest developments in automobile technology it is even possible to say that they are consuming themselves as well. They are now so complex that the average garage mechanic cannot fix them. They are so packed with technologic, cybernetic gadgetry... and god's knows what else... that they represent one of the most total triumphs of technological production we have yet to see. This is particularly amazing and interesting given that they have such a short life in themselves; which is of course another of the specific problems they represent. Once they are scrapped they cannot really be recycled. ${ }^{19}$

This industry is of course related to architecture through suburbia, whether in Britain or America. Milton Keynes in the United Kingdom was a significant turning point in the British case. ${ }^{20}$ There were no more New Towns after that. Developers and government just gave up on the New Town project altogether. Many of its problems were structural in a sense; the theoretical and planning model they used was 


\section{Amps}

fundamentally flawed - and also ideological in nature. ${ }^{21}$

Llewelyn-Davies-Weeks Forestier-Walker and Bor, who developed the strategic planning model of Milton Keynes, were influenced by Melvin Weber; a figure in the background at University College London at the end of the 1960s and the beginning of the 1970s. Weber was an American planner who, in Explorations into Urban Structure, published in the mid-1960s, coined the two phrases; "the non-place urban realm" and "community without propinquity.",2 This thinking is pure ideology. It is based on Los Angeles and the automobile. Its effects have been disastrous.

In this context, the LA case is particularly interesting. We need to remind ourselves when we think of that city, a city that is now inseparable in our minds from the automobile, that it had its own very extensive suburban electric rail system until the end of the Second World War. Its final remnants were eliminated by the early 1950s. The lines were pulled up and replaced by roads and bus companies were bought up. The automobile companies and oil companies were free to take over the transport system of the city. That's the story. That's the model that lies at the core of places like Milton Keynes. ${ }^{23}$ It is certainly not just a story of architecture as an isolated discipline.

\footnotetext{
The issue of suburban development and appropriate templates for housing settlement have been a constant theme in Frampton's writings since the early 1980s. It was a key aspect of his seminal essay Towards a Critical Regionalism: Six Points for an Architecture of Resistance written in $1983 .{ }^{24}$ It was also a theme he returned to, in the context of India, in his contributions to The Architecture of Independence in $1998,{ }^{25}$ and is a theme threaded through the later editions of Modern Architecture: A Critical History. In all these texts, he argues for low rise high density developments; a theme taken up by the New Urbanism movement. Despite this particular similarity in approach, Frampton's response to this relatively recent development in urban design has been circumspect in the extreme. He explains:
}

The great slogan that is tied to New Urbanism is "walkable." Walkable neighbourhood - walkable environment. But that is as far as it goes. In terms of iconography it does not have any vision beyond the idea that, in the name of 'liberal freedom,' developments should be more concentrated. That may well be a positive set of concepts, but they are not connected to any ideas about public transport. That is a major flaw in their approach and it is evident in almost everything done under the banner of New Urbanism. ${ }^{26}$

Much more interesting in terms of people discussing these issues is the radical Cassandra-like figure, James Howard Kunstler. Kunstler has just written a book called Too Much Magic. ${ }^{27}$ Some of his other writings are also interesting in this regard; Geography of Nowhere and Home from Nowhere from the 1990s and The City in Mind: Notes on the Urban Condition more recently. In spite of his radical rhetoric however, through these writings and his analysis of urbanism in the United States, he ends up with a form of New Urbanism as well.

However, Kunstler's more radical argument is that we should give up on this whole auto-route system; that we need to build light rail; that we need to build high speed trains. Now this country is in decline, and partly it is in decline because we cannot go on consuming at the rate we do. Kunstler predicates his 


\section{Amps}

arguments on architecture on this notion of excessive consumption, particularly of oil. He underlines the idea of peak oil; a point that has already been reached. In this context, in which our rate of oil production is in terminal decline, the model of the city based on the automobile, simply becomes unsustainable. ${ }^{28}$

All of this brings us back to the Club of Rome and the 1972 study that led to the book The Limits to Growth. ${ }^{29}$ The authors of this study made computer models to demonstrate the nature of the predicament about our consumption of non-renewable resources. They placed particular emphasis on water, the growth in population and the escalation of pollution. These factors were examined through computer modelling as long ago as the 1960s, and more or less demonstrate that at some point this whole system must collapse. That is the situation we actually find ourselves in today. Architecture undoubtedly has a role to play in dealing with these issues and sustainable urban models are one part of that. New Urbanism fails to address this broader context in any serious way.

\footnotetext{
New Urbanism is a largely US based movement that has been operative since the early 1990s. Milton Keynes, in many ways the antithesis of New Urbanism ideals, was developed in the United Kingdom in the late 1960s and early 1970s. Frampton's writings not only cover this time period but also cover this geographical expanse. In overviews of this extended geographical and historic zone, he has suggested that there is a need for state involvement in planning and housing. He has done this, in part, by highlighting the failure of exclusively private developments in the US since the mid-1970s to develop anything like a viable and sustainable model of urban / suburban living. ${ }^{30}$

Prompted to discuss the role of government in architectural development through the prism the Tony Blair UK governments in the late 1990s, and New Labour's notion of a political "third way," he underlines the relationship developed between the Labour administration and the architect Richard Rogers. He also offers his opinion on the recent developments in the United Kingdom with regard the relaxation of obligations to provide affordable housing in PFI development projects, and the freeing up of green belt by the current Tory government. $^{31}$
}

Considering the relationship between the political establishment and architecture in the cases of Britain and America leads one inevitably to the broader context of the 'special relationship.' This notion running through Anglo-American relations had a direct impact on New Labour, with the Blair government's sellout over the Iraq War. ${ }^{32}$ They must have known perfectly well it was a 'put up job', but they went along with it. It seems that the British are pathological with regard the United States. Having lost their empire they want to be on the coattails of the successor. ${ }^{33}$ It was taken to an extreme in that case.

It has been going on for decades now of course, and not only affects Anglo-American relations, but also Britain's engagement with Europe. The peculiar relationship of Britain to Europe is one of a seemingly endless debate about being part of Europe, or not part of Europe. It continues today and the current government of David Cameron represents the reactionary right wing of that debate.

Now this relaxation of restrictions on greenbelt development by the Cameron government is amazing; another reactionary policy. I'm sure it is not related in any direct way to Anglo-American relations, but as an example of deregulation and retreat of government from engagement with planning policy it would 


\section{Amps}

seem to follow the American model.

A few years ago the situation seemed very different. Richard Rogers was of course a key figure in the UK context and was very close to Blair in the early years of his government. I suppose Richard Rogers could be defined a 'socialist.' He was the chairman of the think tank that produced the government white paper Towards an Urban Renaissance in 1999. ${ }^{34}$ About five years later they produced a follow up report about what had happened in that period. ${ }^{35}$ The question of using brownfield site for development, and the continued restriction of greenfield development during the Blair period, was connected to that report. It was the New Labour policy.

In that sense there was a very positive and direct engagement between architecture and politics in the UK and it produced an important set of ideas. In that first report there was an extraordinary idea: a statement. It made a huge impact on me. Somewhere there is a sentence in the report that states... "we must recognise that ninety percent of that which will exist in twenty years' time has already been built"... I find that an amazing sentence. It was particularly important in the context of England at that time as it had the highest divorce rates in Europe and a high teenage pregnancy rate; issues that contribute to placing greater strain on housing needs.

With regard the United States case, architecture is pretty much completely divorced from political involvement and there is nothing comparable to the relationship between government and architects represented by the Blair - Rogers relationship. However, I suspect that the argument that "ninety percent of that which will exist in twenty years has already been built," may be as true in the US as it is in the UK and its implications are potentially just as significant. However, there is no government involvement particularly at the federal level in the United States.

\footnotetext{
Kenneth Frampton has pinpointed the lack of planning policy and control in the United States as the key factor in opening up American architectural and urban development to the market. Its repeated use of the same models lead to what he has defined as 'universal placelessness. ${ }^{36}$ This universal placelessness, the ubiquitous emergence of the same modern architectural models across the United States and, in a globalised context, across the world, was the underlying issue dealt with in perhaps his most influential essay to date; Towards a Critical Regionalism: Six Points for an Architecture of Resistance, 1983. In this text he holds out the possibility of the critical and selective application of the ideas and technologies associated with modernism in ways that reveal a closer understanding of, and indeed respect for, the specific context in which architecture is built. It is a set of ideas applicable and influential not just in Europe or the United States, but across the globe. Here, he expands on its manifestations in the context of India.
}

Although Critical Regionalism as a concept is clearly relevant to the US and UK cases, the origins of the phrase is in Greece. It comes from Alexander Tzonis and Liliane Lefaivre and the article they wrote in 1981 called The Grid and the Pathway. ${ }^{37}$ It was a form of reflection on the work of Dimitri Pikionis and Aris Konstantinidis; seen as representing two dialectically opposed approaches to architecture. On the one hand the work of Pikionis being read as basically topographic, and that of Konstantinidis being interpreted as a kind of rational structural order. 


\section{Amps}

That article was a big influence on my thinking and subsequently led, two years later, to the writing of Towards a Critical Regionalism. Recently, the idea has been discussed by Frederic Jameson in The Seeds of Time which offers a sort of critique of Critical Regionalism. ${ }^{38}$ It is extremely intelligent and very sensitive. I could never say that this 'generic intellectual' misunderstood what I was talking about. Indeed, he went beyond it, although he is very critical of it from a Marxist standpoint. Despite this, and despite the passing of the years, it is an idea that still floats in the air. It remains a reference in one way or another.

For example, although it doesn't reference Critical Regionalism in any direct way, Atlas Global Architecture circa 2000, edited and published by Luis Fernández-Galiano a few years ago, impressed me very much from this perspective. Subsequently, he published two more books along similar lines; one on the Americas and one on Africa and Asia. Atlas America Architectures of the 21st Century and Africa and Middle East-Atlas Architectures of the $21^{\text {st }}$ Century. ${ }^{39}$

I have proposed an idea to Thames and Hudson that would develop the polemic found in these books in ways more closely aligned with Critical Regionalism. If you cast an eye over the world scene, you find the spectacular star architecture everywhere. However, just beneath the surface of that one can find inflections; variations and individual projects that are more intimately related to the climate and traditions of the site. It is something that the star system simply does not do - cannot do.

Glenn Murcett is a clear example in Australia, but there are others all over the world. One fascinating case for example is Studio Mumbai founded by Bijoy Jain. There is an edition of El Croquis dedicated to Studio Mumbai from 2003-2011, so it is not unknown. ${ }^{40}$ What Bijoy Jain has created there, admittedly mostly in the service of the bourgeois class, is incredible. In Mumbai he has a workshop with craftsman, and everything he has made in this period (2003-2011) has been made in these workshops by craftsman traditional craftsmen. In a sense, it is a reincarnation of a William Morris concept but with very powerful results, both aesthetically and ethically.

The buildings designed by Studio Mumbai are modern, but they have a kind of dreamlike osmosis between what is the legacy of the modern, and that which is much older. They connect with much deeper traditions and, in this sense, reflect perfectly the ideas behind Critical Regionalism. I will be discussing this in a lecture at Karlsruhe that ends with the work of B. V. Doshi and his low rise housing for the poor, constructed between 1983-1986, and with images of Studio Mumbai. As it happens, in the special edition of El Croquis, all of this comes together in an interview between Doshi and Bijoy Jain. ${ }^{41}$ They discuss the relationship between modernism and tradition, and what emerges is a pretty amazing manifestation of Critical Regionalism.

Towards a Critical Regionalism: Six Points for an Architecture of Resistance was published in 1983 and since that time the environmental agenda has come to the fore politically and architecturally. These issues, latent in a sense in Frampton's primary text, have emerged with ever more frequency and urgency in his later works. He comments on this in the light of the recent hurricane to hit New York and in the context of the United States political scene; a scene which between 2000 and 2008 was characterised by the continuous and deliberate undermining of the science of global warming by the federal government of George W. Bush. ${ }^{42} \mathrm{He}$ also discusses the role of the environmental agenda in architectural schools and the society of the United 


\section{Amps}

States more generally.

In this country the importance of dealing with climate change has become fully accepted in architectural circles. You cannot possibly run a school of architecture today without taking these issues on board. However, it is an issue that is not seen culturally; it is an issue that tends to be seen technologically. The basic premise is that we have to design buildings, and high rise buildings, that are ecological. However, it is not seen as a cultural or political issue - it is not formulated like that - it is formulated as a technological fix.

This is of course easier to sell because it is devoid of political connotations. It is totally apolitical. This also allows you to focus on technology as a potential growth technology economically. As is typical of this country, it is dealt with in pragmatic and economic terms. I am not against that formulation but it has its own boundaries. Recent events may mean that this changes however. After Hurricane Sandy the Republican Governor of New Jersey, Chris Christie, came out in support of Barack Obama on the eve of the election. He highlighted Obama's environmental agenda as the key reason for doing so. ${ }^{43}$

Indeed, Andrew Cuomo who is Governor of New York, and Michael Bloomberg who is Mayor of New York, along with Governor Christie, have all embraced the phrase 'global warming' in recent speeches. That's the first time that anybody politically has dared to use this taboo term. It is the first time they have directly acknowledged this condition.... and this is a direct result of Hurricane Sandy.

However, this does not translate into political considerations of architecture in these terms. The only sense in which you see a political consideration of architecture is over the issue of land settlement; the idea that there should be a totally different approach towards land settlement. That is an architectural issue that sometimes emerges in the political arena. It is evident in the argument that there should be more concentrated land settlement and less sprawl. Even in this regard however, it is quite rare that any politician or public figure gets involved directly.

I suppose one could argue that James Howard Kunstler, who I mentioned earlier, is a public figure who engages directly with these issues. However, he is a rabble rousing radical figure to one side of any mainline political discourse. He has a blog called Clusterfuck Nation.$^{44}$ It is extremely polemic, as is his recent book Too Much Magic. They are both outlets for radical thought, but there is a lot of logic to their arguments. Another radical figure of importance in the United States is Cornel West; a radical philosopher with an important reputation.

He is an Afro-American professor who taught at Harvard for some time, but actually fell out with the president, Larry Summers, who treated him with incredible contempt. He left and is now a professor at Princeton. Recently, he described Barack Obama as a 'crypto-fascist.' He argues that the US government's international hit-list of assassinations and the use of drones (all directly related to the present Obama administration), together with the neglect of the poor in his first term, is just 'fascism.'

It is a radical position, but that is his opinion. He caused an enormous storm by being Afro-American and making this attack on the only Afro-American President in history. ${ }^{45}$ It is relevant to architecture, indirectly, in the context of the neglect of the poor - in terms of a lack of interest in social housing. If one considers the origins of the modern movement, this was clearly an issue that linked thinking about 


\section{Amps}

architecture with politics in a way that simply does not occur here in the United States where architecture

is seen as largely apolitical in a direct sense. It is the antithesis of where we started, with comments of Hannah Arendt and the influence of her views on architecture, which are directly political. This is an apolitical country in a sense; a strange country passing through a strange time.

Architecture_MPS has developed a new genre of academic writing; the 'interview-article'. It is a variation on the interview genre in which theoretical background is added for the reader through extensive and discursive notation that expands on the arguments and references made by the interviewer or the interviewee. It is an explanatory / descriptive adaptation of the standard interview format that makes it a hybrid academic literary form.

This article is available on the agreed terms of open access. Users are allowed to read, download, copy, distribute, print, search, or link to the full texts of the articles in this journal without asking prior permission from the publisher or the author. This is in accordance with the BOAI definition of open access. Users are expected to fully cite and reference the sources of any material accessed under this agreement. The image used here is from Kenneth Frampton's book: Modern Architecture: A Critical History. Thames and Hudson, London, 2007. For information see: http://www.thamesandhudson.com. For information on the journal see: http://architecturemps.com 


\section{Amps}

${ }^{1}$ Paul B Jaskot, review of Labour, Work and Architecture: Collected Essays on Architecture and Design by Kenneth Frampton, The Journal of the Society of Architectural Historians 63, no. 1 (2004), 126.

${ }^{2}$ Kenneth Frampton, Labour, Work and Architecture: Collected Essays on Architecture and Design (London: Phaidon, 2002$), 7$.

${ }^{3}$ Ibid.

${ }^{4}$ The ideas referenced here are found in Arendt's 1958 The Human Condition. Hannah Arendt, The Human Condition. 2nd edition (Chicago: University of Chicago Press, 1998).

${ }^{5}$ This underlining of architecture as dualistic in character is one of the ideas that Paul B. Jaskot emphasises in comments on Kenneth Frampton's interpretation of Hannah Arendt. Jaskot, Review of Labour, Work, 126.

${ }^{6}$ Debord's book was originally published in French in 1967. Guy Debord, The Society of the Spectacle (Detroit: Black and Red Publications, 2006).

${ }^{7}$ Kenneth Frampton discusses the CCTV building in the 2007 edition of Modern Architecture: A Critical History, in which he defines it as "a gargantuan representation of manipulative media power." Kenneth Frampton, Modern Architecture: A Critical History. 4th edition (London: Thames and Hudson, 2007), 345.

${ }^{8}$ Kenneth Frampton has written numerous monographs of modern architects. He deals with the work of Tadao Ando in the 2003 publication, Tadao Ando: Light and Water (New York: The Monacelli Press, 2003).

${ }^{9}$ Frampton, Modern Architecture, 200-222.

${ }^{10}$ Kenneth Frampton. “The Other Corbusier: Primitive Form and Linear City, 1929-52”. In Labour, Work and Architecture, $219-225$.

${ }^{11}$ In Modern Architecture: A Critical History Kenneth Frampton suggests (pp.223-221) that the Rockerfeller Center is, in many ways, the epitome of this; a speculative high rise produced during the depression through an opportunistic alliance with the "fledgling" communications industry; specifically The Radio Corporation of America.

${ }^{12}$ These ideas are found in the work of, Lionello Benevelo. Lionello Benevelo, History of Modern Architecture. Volumes 1 and 2 (Massachusetts: MIT Press, 1971).

${ }^{13}$ Kenneth Frampton discusses Sullivan and Adler in more detail in: "Adler and Sullivan: The Auditorium and the High Rise 1886-95". Frampton, Modern Architecture, 51-56.

${ }^{14}$ Owen Jones was an influential nineteenth century English architect and interior designer. Known for his studies of the Alhambra in Granada, Spain, he was also a key figure in the development of what would become the Victoria and Albert Museum in London. Furthermore, he set the framework for the decorative art principles applied in the forerunner to the Royal College of Art, London. His most famous text was The Grammar of Ornament published in 1856. Owen Jones, The Grammar of Ornament (Berlin: Deutsch Press, 2010).

${ }^{15}$ For a typical example of his encyclopedic examination of architecture as a multiple and complex amalgam of influences, see his description of the social and cultural factors leading up to the architecture of the modern age. Kenneth Frampton, "Cultural Developments and Predisposing Techniques 1750-1939," in: Frampton, Modern Architecture, 12-40.

${ }^{16}$ Descriptions of Speer's architecture and its relation to the Nazi regime and representations of power are found in the architect's memoirs written whilst serving a twenty year prison sentence between 1946-1966. Albert Speer, Memoirs: Inside the Third Reich (London: Simon \& Schuster, 1997). A reappraisal of his architecture is offered in: Leon Krier, Albert Speer: Architecture $1932-1942$ (Archives D'Architecture Moderne, 1985).

${ }^{17}$ The Triumph of the Will was released in 1935. It documents the 1934 Nazi Party Congress in Nuremberg. As a Nazi propaganda film it was followed in 1938 by Olympia. Both films represent formal experimentations with the then relatively new medium of film. They have been extensively documented in various books. A typical example is: David Hinton, The Films of Leni Riefenstahl. 3rd edition. (Maryland: Scarecrow Press, 2000).

${ }^{18}$ Grunberger's book examines a wide variety of ways in which propaganda and social strategies were used by the Nazi regime to create the social conditions possible for the political events of the Nazi period in Germany. One example is the photograph discussed by Kenneth Frampton. Richard Grunberger, The 12-year Reich: A Social History of Nazi Germany 1933-1945 (New York: Da Capo Press, 1995).

${ }^{19}$ A concern for an environmentally sound approach to urbanism and architecture has become increasingly prevalent in the writings of Kenneth Frampton. It emerges in comments about the works of Norman Foster and Renzo Piano in: Kenneth Frampton, The Evolution of $20^{\text {th }}$ Century Architecture: A Synoptic View (New York: Springer-verlag/Eiwn, 2007), 131-136. It is also evident in later editions of Frampton, Modern Architecture, 361-369

${ }^{20}$ Milton Keynes is the UK's most iconic modern town development. For an overview, see: Derek Walker, The Architecture and Planning of Milton Keynes (London: The Architectural Press, 1982).

${ }^{21}$ Kenneth Frampton discusses the case of Milton Keynes in Modern Architecture, 286-287.

${ }_{22}^{2}$ Melvin Webber, Explorations into Urban Structure (Philadelphia: University of Pennsylvania Press, 1964).

${ }^{23}$ This story of the move from rail to the use of the automobile in the case of Los Angles was examined from a much more positive perspective by Reyner Banham. See: Reyner Banham, Los Angeles: The Architecture of Four Ecologies. 2nd edition. (Los Angeles: University of California Press, 2009).

${ }^{24}$ Kenneth Frampton, "Towards a Critical Regionalism: Six Points for an Architecture of Resistance," in Labour, Work and Architecture: Collected Essays on Architectural Design, ed., Kenneth Frampton (London: Phaidon, 2002), 76-89.

${ }^{25}$ Kenneth Frampton, introduction to Architecture of Independence: The Making of Modern South Asia, edited by Kazi Khaleed Ashraf \& James Belluardo, 10-12 (New York: The Architectural League of New York, 1998).

${ }^{26}$ The New Urbanism movement is organised through the Congress for the New Urbanism founded in 1993. Its founding members are Peter Calthorpe, Michael Corbett, Andrés Duany, Elizabeth Plater-Zyberk, Stefanos Polyzoides and Daniel Solomon. It runs international conferences and lobbies state governments on urban design issues. Its concepts are defined in the text: Congress for the New Urbanism. Charter of the New Urbanism (New York: McGraw-Hill Professional, 1999).

${ }^{27}$ James Howard Kunstler, Too Much Magic: Wishful Thinking, Technology, and the Fate of the Nation (New York: Atlantic Monthly Press, 2012).

${ }^{28}$ Kunstler's arguments on the effects of Peak Oil for urban living began with the 2005 publication of The Long Emergency. Since 2008 he has also written a series of science fiction / futuristic novels such as The World Made by Hand. James Howard Kunstler, The Long Emergency: Surviving the End of Oil, Climate Change, and Other Converging Catastrophes of the Twenty-First Century (New York: Grove Press, 2006); The World Made by Hand (New York: Grove Press, 2006).

${ }^{29}$ Donella Meadows, Jørgen Randers and Dennis Meadows, The Limits to Growth (New York: Signet, 1972). 


\section{Amps}

${ }^{30}$ Frampton, Modern Architecture, 377.

${ }^{31}$ The Private Finance Initiative (PFI) was particularly used under the UK Labour governments, 1997 - 2010. It has been the subject of much criticism throughout that period and was subject to changes in 2012 by the Conservative party, particularly through the economic policies of George Osborne. See: Campbell, Denis, James Ball, and Simon Rogers, "PFI will ultimately cost £300bn,” The Guardian, July 5, 2012; Rajeev Syal, "George Osborne plans deregulation of planning laws," The Guardian, September 2, 2012.

32 The most thorough analysis of the Tony Blair Labour Party in the context of foreign conflict is John Kampfner's Blair's Wars in which he proposes an analysis of the philosophy underlying these interventions and Blair's attempts to place Britain at the forefront of the changing world order. John Kampfner, Blair's Wars (New York: Free Press, 2004)

${ }^{33}$ Here Kenneth Frampton highlights an issue central to UK foreign policy since the end of World War II. It is covered extensively in: Christopher John Bartlett, The Special Relationship: A Political History of Anglo-American Relations Since 1945 (London: Longman Group, 1992)

${ }^{34}$ Richard Rogers (The Urban Task Force), Towards an Urban Renaissance (London: Routledge, 1999).

${ }^{35}$ Richard Rogers (The Urban Task Force). Towards a Strong Urban Renaissance (London: Routledge, 2005).

${ }^{36}$ Frampton, Towards a Critical Regionalism, 84-85

${ }^{37}$ Alex Tzonis and Liliane Lefaivre, "The Grid and the Pathway: An Introduction to the Work of Dimitris and Suzana Antonakakis", Architecture in Greece (1981) 15, Athens, 164-178.

${ }^{38}$ Frederic Jameson, The Seeds of Time (New York: Columbia University Press, 1996).

${ }^{39}$ Luis Fernández-Galiano, Atlas Global Architecture circa 2000 (Madrid: Fundación BBVA \& Arquitectura Viva, 2008); Atlas America Architectures of the 21st Century (Madrid: Fundación BBVA \& Arquitectura Viva, 2011); Africa and Middle East - Atlas Architectures of the 21st Century (Madrid: Fundación BBVA \& Arquitectura Viva, 2012).

${ }^{40}$ Fernando Máquez Cecilia, Richard Levene, Richard, Studio Mumbai Architects, eds. Studio Mumbai. 2003-2011. El Croquis 157, (2011).

41 "Excerpts from an ongoing dialogue [a conversation between Dr. Balkrishna v. Doshi and Bijoy Jain (with the participation of Rajeev Kathpalia and Durganand Balsavar)]." El Croquis 157 Studio Mumbai. 2003-2011: (2011).

${ }^{42}$ This context has been passionately document by the environmental attorney Robert F. Kennedy Jr. See: Robert F. Kennedy, Crimes Against Nature: How George W. Bush and His Corporate Pals Are Plundering the Country and Hijacking Our Democracy (New York: Harper, 2004).

${ }^{43}$ The political implications mentioned here were also evident in a similar reaction by the Republican Governor of New York, Michael Bloomberg. See: Kate Zernike, "One Result of Hurricane: Bipartisanship Flows," New York Times, October 31, 2012; Raymond Hernandez, "Bloomberg Backs Obama, Citing Fallout From Storm," New York Times, November 1, 2012.

${ }^{44}$ James Howard Kunstler, "Clusterfuck Nation.” http://kunstler.com/blog/

${ }^{45}$ Cornel Ronald West is an American professor and author and member of Democratic Socialists of America. He teaches African American Studies at Princeton. He is the author of numerous books including, most recently, The Rich and the Rest of Us: A Poverty Manifesto (New York: Smiley Books, 2012). See also: http://www.cornelwest.com 


\section{Amps}

\section{Bibliography}

1. Arendt, Hannah. The Human Condition. Chicago: University of Chicago Press, 1998.

2. Benevelo, Lionello. History of Modern Architecture. Volumes 1 and 2. Massachusetts: MIT Press, 1971.

3. Campbell, Denis, James Ball, and Simon Rogers. "PFI will ultimately cost $£ 300 b n . "$ The Guardian, July 5, 2012.

4. Debord, Guy. The Society of the Spectacle. Detroit: Black and Red Publications, 2006.

5. Fernández-Galiano, Luis. Atlas Global Architecture circa 2000. Madrid: Fundación BBVA \& Arquitectura Viva, 2008.

6. ---. Atlas America Architectures of the 21st Century. Madrid: Fundación BBVA \& Arquitectura Viva, 2011.

7. ---. Africa and Middle East - Atlas Architectures of the $21^{\text {st }}$ Century. Madrid: Fundación BBVA \& Arquitectura Viva, 2012.

8. Frampton, Kenneth. Labour, Work and Architecture: Collected Essays on Architecture and Design. London: Phaidon, 2002.

9. ---. "The Other Corbusier: Primitive Form and Linear City, 1929-52". In: Labour, Work and Architecture: Collected Essays on Architecture and Design, 219-225. London: Phaidon, 2002.

10. ---. “Towards a Critical Regionalism: Six Points for an Architecture of Resistance”. In Labour, Work and Architecture: Collected Essays on Architectural Design, 76-89. London: Phaidon, 2002.

11. ---. The Evolution of Twentieth Century Architecture: A Synoptic View. New York: Springerverlag/Eiwn, 2007.

12. ---. Modern Architecture: A Critical History. 4th edition. London: Thames and Hudson, 2007.

13. ---. Introduction to Architecture of Independence: The Making of Modern South Asia, edited by Kazi Khaleed Ashraf \& James Belluardo, 10-12. New York: The Architectural League of New York, 1998.

14. Grunberger, Richard. The 12-year Reich: A Social History of Nazi Germany 1933-1945. New York: Da Capo Press, 1995.

15. Jameson, Frederic. The Seeds of Time. New York: Columbia University Press, 1996.

16. Jaskot, Paul B. review of Labour, Work and Architecture: Collected Essays on Architecture and Design by Kenneth Frampton, The Journal of the Society of Architectural Historians 63, no. 1 (2004). 


\section{Amps}

17. Jones, Owen. The Grammar of Ornament. Berlin: Deutsch Press, 2010.

18. Kunstler, James Howard. “Clusterfuck Nation.” http://kunstler.com/blog/

19. ---. Too Much Magic: Wishful Thinking, Technology, and the Fate of the Nation. New York: Atlantic Monthly Press, 2012.

20. Fernando Máquez Cecilia, Fernando, Richard Levene, Studio Mumbai Architects, eds. Studio Mumbai. 2003-2011. El Croquis 157, (2011).

21. Meadows, Donella, Randers, Jørgen \& Dennis Meadows. The Limits to Growth. New York: Signet, 1972.

22. Rogers, Richard (The Urban Task Force). Towards an Urban Renaissance. London: Routledge, 1999.

23. ---.Towards a Strong Urban Renaissance. London: Routledge, 2005.

24. Syal, Rajeev. "George Osborne plans deregulation of planning laws." The Guardian, September 2, 2012.

25. Tzonis, Alex and Liliane Lefaivre. "The Grid and the Pathway: An Introduction to the Work of Dimitris and Suzana Antonakakis." Architecture in Greece (1981) 15, Athens, 164-178.

26. Webber, Melvin. Explorations into Urban Structure. Philadelphia: University of Pennsylvania Press, 1964. 